\title{
ЧІЛЬНИЙ АКЦЕНТ СУЧАСНОСТІ: МЕДІАТИЗАЦІЯ КОНЦЕПЦІЇ САМОВИЗНАЧЕННЯ ОСОБИСТОСТІ І СПІЛЬНОТИ
}

\author{
Йосип Лось \\ Львівський національний університет імені Івана Франка, \\ вул. Генерала Чупринки, 49, 79044, Львів, Україна, \\ e-mail: jlos@gmail.com \\ https://orcid.org/0000-0002-7531-8043
}

Розглянуто на основі сучасних досліджень ідентифікації людської особистості й національної та соціальної спільноти (наукові ресурси і мас-медіа) питання визначення суті й ролі особи і спільнот у сучасних умовах «зміни епох» - від тотальної стривоженості до органічного упорядкування буття.

Ключові слова: особистість, спільнота, ідеали, ідентичність, сучасність, мас-медіа, аргументація, органічність, історична свідомість.

Постановка проблеми. Обгрунтовано примат ідеалів, закодованих в суцільній історичній пам'яті народів, від мотивації Рігведи («Нехай прийдуть благородні думки до вас з усіх сторін») до орієнтації на «шляхетно здисципліновані душі» (Гете), цілеспрямованої апеляції «бути людьми», сповідуючи «святую правду-справедливість» (Тарас Шевченко), орієнтації на мету буття - «цивілізацію любові», «соціальне милосердя» (Іван Павло II). Фундаментальні дослідження фахівцями «вищої ліги журналістики» - власне світоглядної публіцистики - сценарію, який базується на матеріалістичному нігілізмі й керує долею планети, результатом чого є моральне виснаження народів і сучасної цивілізації назагал, знесенсовнення буття у мас-медіа, зіставляється 3 макротекстами, що обгрунтовують перспективи життя в оптимістичному світі, доводять потребу формування світоглядно-орієнтаційних засад якісно нової епохи, полегшують людям здійснення їх життєвого призначення творити добро - адже усе, що нелюдське, є безсенсовним і даремним, як довела історія.

Йдеться рівно ж про роль Слова, що Визволяє, а не поневолює, про гідність мислення журналістів - Апостолів Істини. Тому, за польським вченим Гжегожем Янковічем, «власну та ідентичність дійсності довкола нас трактуємо як текст, сенс якого не є завчасно і раз назавжди даним, натомість виакцентовується у процесі читання, є ефектом інтерпретації - одного з найбільших наших винаходів. Якби ми не творили значень, неможливим було б налагодження відносин між людьми, неможливим було б також будувати і жити на світі» [1].

(С) Лось Й., 2019 
Лось Й.

Отож використовуємо ряд авторитетних досліджень проблеми: Барг М. А. Эпохи и идеи. - М., 1987; Колінгвуд Робін Дж. Ідея історії. - К., 1996; Ясперс Карл. Психологія світоглядів. - К., 2009; Помян Кшиштоф. Свропа та ії нації. - Львів, 2003; Мандер Джерри. Когда не остается ничего святого. Провал технологий и судьба коренных народов. - К., 2007; Церква і соціальні проблеми. - Львів, 2000; Онацький Євген. Портрети в профіль. - К., 2016; Єрмоленко Анатолій. Кореляція культури і цивілізації в становленні української модерної ідентичності. - Вісник Львівського університету. Серія філософські науки. Випуск 20. - 2018. - C. 9-20; Jan Pawel II. Wiara i kultura - Rzym-Lublin, 1988; Dziennikarski etos. Z wybranych zagadnien deontologii dziennikarskiej. - Olsztyn, 1996; Puzynina Jadwiga. Słowo - Wartość - Kultura. - Lublin, 1997; Picard Robert G. Kto oddzieli ziarno od plew. - Gazeta Wyborcza. - 2013, 5-6 pazdziernika (див. також бібліографію).

\section{НАЦІЯ, СОЦІУМ, ОСОБИСТІСТЬ:}

\section{Діагноз. Пошуки альтернатив. Перспективи}

На початку кілька засадничих речей. Історія як навчителька життя довела, що людство безперестанку шукало достойнішу модель співжиття, ніж існуючий тотальний і безнадійний «прогрес», рівно ж - неминучість перемоги добра над злом. Зрештою, усі імперії, чи мілітарно-політичні, диктаторські, чи імперії зиску - розпадаються. Мотором історичного процесу посутньо є пошук та реалізація властивої, тобто морально-ціннісної ідентичності. Вписуючись у порядок Всесвіту, далекоглядні особистості, у тому числі публіцисти, доводили доконечну потребу рівноваги упорядкованості буття і свободи як істини, плекання культури як образу душі народу, причому доконечно важливе поєднання ії з етнічними структурами. Застановімося над думкою Василя Лісового: «Звуження генетичного фонду - велика втрата для людства... Чим життя важливе? Для нас, нашого народу це значить: як витворити оце відчуття архетипів культури, цих святинь нашої культури так, щоб був інтимний зв'язок з нашою історією, з нашими предками, які...побудували добрі стосунки $з$ природою; культ предків існував як цінність. До того ж розрив із еволюцією спричиняє великі трагедії» [2; 21]. Юрій Липа, до слова, цю проблематику глибоко розробив у книзі «Призначення України».

Методологічним доповненням цих висновків можуть служити такі два принципово важливі положення, що їх багато разів використовували вчені та журналісти. Отож Іван Франко: «Все, що йде поза рами нації, се або фарисейство людей, що інтернаціональними ідеалами раді би прикрити свої змагання до панування одної нації над другою, або хворобливий сентименталізм фантастів, що раді би широкими «вселюдськими фразами» покрити своє духове відчуження від рідної н а цї̈. Може бути, що колись надійде пора консолідування якихсь вольних міжнародних союзів для досягнення вищих міжнародних цілей. Але се може статися аж тоді, коли всі н а ц і о н а л ь н і змагання будуть сповнені і коли національні кривди та неволення відійдуть у сферу історичних споминів. А поки що треба нам із чеським поетом стояти на тім:

У зорях небесних великий закон

Написаний, золотолитий,

Закон над закони: свій рідний край

Над все ти повинен любити

(Із «Космічних пісень» Яна Неруди) [3; 276-285]. 
Микола Сціборський натомість посутніше від багатьох світових теоретиків держави та суспільства обгрунтував принципи, що їх сьогодні знову втілюють в життя, саме у контексті процесу новітньої ідентифікації: «Держава - це не лише організована доиільність; це насамперед святе святих нації, що зобов'язує кожного громадянина до служіння, жертв і високих духовних поривів.

Не внутрішня боротьба часткових інтересів, тільки солідарні, узгіднені зусилля цілого суспільства, спрямовані на забезпечення сили й ладу держави, можуть гарантувати в лоні нації всім іiї прошаруванням внутрішній мир, охорону, працю, законність, соціальну справедливість і розвиток» [4; 74].

Ситуація ніколи не буває розпачливою. Важливо прагнути внести свій вклад до невпинного розвитку людської цивілізації, аби взяти на себе відповідальність за майбутній добробут людства. Найвищою метою діяльності має стати і збереження глобальної біосфери, і забезпечення творчого потенціалу та розмаїття культур і націй. Пам'ятаймо: насамперед усе, що мало місце протягом століть і тисячоліть, несе печать минулого часу. Тому якнайпильнішим предметом історичного дослідження в онтологічному плані, себто так, як було, а не так, як історичні факти заломлюються у призмі суб'єктивного підходу, повинні стати уроки, а не механічне перенесення тогочасних історичних реалій у сучасні умовини, бо це нонсенс психологічний, науковий, онтологічний.

Якщо ми зосередимося бодай на одному, XX столітті, то найголовніший його урок стисло висловила газета «Нью-Йорк Таймс» у редакційній статті за 26 січня 1995 року: «Кажучи песимістично, наше століття можна назвати століттям Сатани. Ще ніколи в історії люди не виявляли такої схильності, такого бажання вбивати мільйони інших людей через расову, релігійну чи класову приналежність». Катастрофічна доба безладдя, коли вчинено стільки політичного, соціального, економічного та іншого зла при колосальному науковому потенціалі до добра, змушувала багатьох морально та інтелектуально оснащених публіцистів (дуже часто вони виступають також як вчені, письменники, культурологи, духовні особи) ставити засадничі питання: «Чому?», «Де джерело зла?».

Із сотень концептуальних публікацій такого плану назвемо декілька типових 3 різних країн, років, видань. У «Філософських дослідженнях про суть людської свободи...» Фрідріха Шеллінга фахівці з царини німецького романтизму звернули увагу на глибоку думку про те, чому так повільно і з великими блуканнями розвивається людський рід. Відповідь він дав багатоаспектну: це входить в задум Бога про світ і людину. Усе покликане удосконалюватися абсолютно добровільно; сили, що протистоять собі, повинні повністю виявити свою волю таким чином, щоб злі саморозвінчалися і вичерпали себе до споду, відтак, можливо, стали спроможними на метаморфозу, на звернення до блага. Принагідно: інший представник цієї течії Йоганн Готтфрід Гердер під впливом актуальності «українського питання» в тогочасній європейській політиці після поразки виступу Івана Мазепи прорік, що «Україна стане новою Грецією. Гарне небо цього народу, його весела вдача, його музикальна натура, його родюча земля і т. д. колись прокинуться; з численних малих диких народів, якими також колись були греки, постане культурна нація. Iї кордони простягнуться аж до Чорного моря, а звідти - через увесь світ» [5; 39].

Індієць Ауробіндо в грунтовному есеї «Людський цикл» майже сто років тому довів неминучість переходу комерційної цивілізації в духовну. Іспанець Ортега-і-Га- 
сет в нарисі «Бунт мас» переконливо довів згубність споживацького суспільства. Ленс Морроу в американському тижневику «Тайм» опублікував розгорнуту й тематично системну статтю-огляд під назвою «Зло». Вже сама постановка проблеми, починаючи від посилання на «Книгу Йова», цього блискучого трактату про таємницю зла, і закінчуючи запитаннями-очікуваннями про можливість «усунути всі сліди споконвічного зла, підлості, насильства, племінної ворожнечі, жадоби вбивати», водночас - «чи втрачає добро свій сенс і призначення у світі», спонукує до за м и сленн я (евристичний текст). Бо ж потім енциклопедично виразно проаналізовано доведені факти вселенських «апокаліпсисів», від двох світових воєн, геноциду вірменів, українців, євреїв, кампучійців та інші зловіщі приклади заглади мільйонів людей. Навіть короткі спогади про зміни на краще останнім часом, наведений «чорний послужний список» людей Землі - це попередження на майбутнє [6; 8-9].

Оригінально «підсумувало» XX століття впливове польське суспільно-релігійне видання «Тижневик для всіх» (Tygodnik Powszechny). 3 нагоди 55-річчя журналу 1 квітня 2000 року простору залу Ради Суспільно-Королівського Міста Кракова заповнили тисяча осіб. Вони стали учасниками «Суду над XX століттям». За усіма правилами правової держави видатні вчені, кіномитці, літератори, політики, культурологи та журналісти (автором ідеї та сценарію «Суду» й був відомий публіцист Пьотр Мухарський (Piotr Mucharski)) чотири години усебічно обговорювали здобутки і злочини епохи - з восьми звинувачень:

1. Чи оскаржений винен через результати легковажної довіри розумові? Винен;

2. Чи оскаржений винен у поневоленні людини через підпорядкування iï масі? Винен;

3. Чи оскаржений винен у практикуванні демократії як владу більшості, тобто як чисту процедуру? Не винен;

4. Чи оскаржений винен у деградації вартості людського життя? Винен;

5. Чи оскаржений винен у поділі світу на багату Північ і бідний Південь? Не винен; Не винен;

6. Чи оскаржений винен у безвідповідальному використанні наукових відкрить?

7. Чи оскаржений винен у тому, що людину позбавлено спроможності раціонального пошуку сенсу життя? Не винен;

8. Чи оскаржений винен у перериванні тяглості пам'яті і відтак знищенні тривалості культури та заміну ії масовою культурою? Не винен.

Повний запис «суду» був опублікований на восьми сторінках додатку до спеціального номера [7].

Індивідуальне буття національності як динамічної цінності дозволяє виявити найперспективніше загальнолюдське. Збагнути сенс цього через різнопланові аргументи дозволяють (вибірково, як золотий фонд публіцистики, крім названих вище) публікації спеціального номера журналу «Кур’єр ЮНЕСКО» - «Універсальність - поняття європейське?» (1992, вересень-жовтень); системна розмова Артура Домославського з Ришардом Капусьцінським про спадок народів, механізм «чорно-білого» мислення сучасних мас-медіа, перехід «Європи-світу» до «Європи у світі», культуру праці, гідного потрактування й визнання самовизначення особистості й спільноти, історичність свідомості, потребу наново переосмислити світ («Ciszej z tymi werblami». - Gazeta Wyborcza. - 2002, 24-26 grudnia. - S. 16-19); підсумкові 
судження Ігоря Сюндюкова про круглий стіл у Національному інституті стратегічних досліджень на тему «Історична пам'ять як поле змагань за ідентичність», зокрема про поставлену Євгеном Сверстюком проблему - чим відрізняється історична пам’ять у кожного конкретного народу (Див.: «Право бути собою». - День, 24 квітня 2008 року. - С. 1, 4); стаття Ніла Габлера «Кінець світу ідей» 3 газети «Нью-Йорк Таймс», яка орієнтує читача на найважливішій функції ідей - не лише пізнати світ, але насправді його зрозуміти, тимчасом ми живемо у світі постідей, вони змізерніли (Opinion. The Elusive Big Idea. By Neal Gabler. - The New York Times. - 2011, August 13); рецензія Декки Ейткенгед (Decca Aitkenhead) на книгу Гарвардського професора політичної філософії Майкла Сендела (Michael Sandel) «Чого не купиш за гроші» у ній засуджують нинішні орієнтири на вигоду, коли кожна людська активність оцінена та обернена в товар і всі оціночні судження замінені простим питанням: «Скільки?» (The Guardian. - 2012. 06); промова Світлани Алексієвич на врученні їй Премії миру Союзу німецьких книгопродавців, повністю передрукована газетою «День» (Див.: Світлана Алексієвич: «Я спускалася в пекло, щоб знайти людину». Білоруська письменниця Світлана Алексієвич розмірковує про феномен «червоної людини». - День. - 2013, 12 листопада); стаття Джеймса Мейса «Європа: матеріалізація привидів», у якій через бінокулярний історичний зір йдеться про постгеноцидний синдром роздвоєння в Україні, нерішучість європейських політиків, про лінію «європейського цивілізаційного розлому, який має політичний і світоглядний характер і пролягає по невидимих кордонах довоєнної радянщини, де збирали свої криваві жнива голодомори, репресії... Донині існує небезпека творення штучних політичних і соціальних конструкцій та схем, які розділяють, а не об’єднують інтелектуалів світу. За позірною їхньою аксіоматичністю ховається не просто чванькуватість західних мислителів, а культурний і соціальний расизм» (Джеймс Мейс. Європа: матеріалізація привидів. - День. - 2014, 14-15 лютого. - С. 22); стаття-дослідження Надзвичайного і Повноважного Посла України Олександра Сліпченка «Сто років тому в Парижі...», в якій на основі архівних матеріалів, публікацій тодішньої преси відтворено недалекоглядність провідних європейських політиків, а також невміння української еліти сконсолідуватися у вирішальні історичні моменти (Дзеркало тижня. $-2019,16$ березня. - С. 15$)$.

Два приклади предметних досліджень мас-медіа заслуговують на ширше тлумачення й наукове узагальнення. Газета «Гардіан» (The Guardian) у числі за 19 жовтня 2011 року вмістила фундаментальну статтю Річарда Готта (Richard Gott) «Малий великий міт». Англійський історик, фахівець з ділянки колоніальних загарбань, автор книги «Британська імперія. Опір. Репресії. Бунт» (Britain's Empire. Resistance, repression and revolt) спростовує сфальшований образ колоніальних завоювань своєї країни. Згадуючи минуле «з набожною повагою», політики усіх партій не беруть до уваги позицію пригнічених народів. Поява британської імперії спричинила забарвлення мапи світу червоним кольором армійських мундирів британців. Колір цей, стверджує автор, дуже пасував до контексту, оскільки імперія була збудована і два століття структурно утримувалася на шляху розливу крові поневолених народів. А також війнами, несамовитою жорстокістю і визиском. Книга рясніє фактами епідемій, невільництва, битв, катувань, масових винищень мільйонів людей. Водночас були й великі жертви серед окупантів, яких насильно мобілізовували до війська чи висилали в колонії. 
Лось Й.

Імперію збудовано на територіях, що належали іншим народам - звідси шалений опір автохтонів, які не мирилися з фізичною та культурною екстермінацією. Згадаймо бодай бунт сипаїв в 1857 році, жорстоке придушення повстання на Ямайці в 1867 році, масакру в Амрістані у 1919 році. Річард Готт: «Цього не вдасться замовчати. Однак масштаб і тривалість імперських репресій протягом десятиліть ніколи не були задокументовані належним чином». Особливий акцент зроблено на долі ірландців, які «ніколи не зрікалися своїх коренів».

Аналізуючи колоніальні завоювання іспанців, португальців, голландців, французів, італійців, німців і бельгійців, автор книги й у статті в авторитетній газеті наголошує на пограбуванні підкорених народів - відтак це стало мотором розвитку Європи протягом чотирьох століть, які й змінили обличчя світу. Висновок Р. Готта: «Досвід Британії можна порівняти з навалами Чінхісхана... Володарі Британії стали організаторами перших масових злочинів проти людства, таким чином можуть конкурувати з диктаторами XX століття... Елімінація «недолюдків», оголошена історичною необхідністю, допомогла збудувати фундамент расистських ідеологій, які розплодилися у Європі. Технічний прогрес збільшив рівень винищень, що їх здійснено раніше».

Матеріал супроводжується переконливою статистикою - від початку експансії в 1573 року до 1997 року, коли Гонконг приєднано до Китаю згідно з порозумінням від 1984 року, а також фотоілюстраціями [8].

Маємо ще один приклад, але вже наскрізь фальшивої інтерпретації історії-вже речниками російсько-ординського й російсько-більшовицького імперіалізму, дотичного до долі України аж під сучасну пору. В Україні, Польщі, інших країнах вже відтворено «хронометраж» і сутність цього експериментального, водночас звироднілого явища світової історії. Долучилися до цього й деякі чесні російські інтелектуали. В аргументації варто й надалі використовувати судження та висновки знакових постатей про сутність Росії як субстанції. Ось Петро Чаадаєв: «Ми, можна сказати, народ винятковий. Ми належимо до числа тих націй, які мовби не входять у склад людства, а існують лише для того, щоб дати світові певний важливий урок» [9]. Також рекомендуємо прочитати упорядковане професором Мар'яном Житарюком перше видання творів П. Я. Чаадаєва українською мовою «Філософічні листи. Апологія божевільного. Уривки та різні думки (1828-1850-ті роки)» [21].

Повчальними залишаються донині, можливо - навіть особливо сьогодні! - такі витяги 3 книги французького дослідника Астольфа де Кюстіна «Росія 1839 року»: «У народі - давке відчуття тривоги, в армії - неймовірне звірство, в адміністрації терор, що поширюється навіть на тих, хто тероризує інших, у церкві - низькопоклонство і шовінізм, серед знаті - лицемірство й святенництво, серед нижчих класів - невігластво й крайні злидні. I для всіх і кожного - Сибір. Ось така ця країна, якою ії зробила історія, природа чи Провидіння... Милосердя вважається слабкістю у народу, вихованого терором» [10; 36-38]. У «Короткому звіті про подорож» Кюстін пояснює: «У росіян не було середньовіччя, у них немає пам'яті про давнину, нема католицизму, рицарського минулого, поваги до свого слова; вони донині залишаються візантійськими греками - по-китайськи церемонно ввічливі, по-калмицьки грубі або, принаймні, нечутливі, з ангельською красою і диким неуцтвом (за винятком жінок і декого з дипломатів), по-жидівськи хитрі, по-холопськи пронирливі, 
по-східньому спокійні й важливі своїми манерами, по-варварськи жорстокі у своїх почуттях; вони презирливо насмішкуваті від безнадійності...» [11; 214]

Чітко обгрунтовану передмову до книги Кюстіна у квітні 1958 року написав Дмитро Донцов - йдеться про «чортівський московський «ерзац» почуття, яке ставить вище над людину свою мету», ординську мету «красти, мордувати, грабувати і панувати», дикунську вдачу, «байдужу до святости даного слова, до всякого правдивого почування, до почуття справедливости», сутність суспільства, «упорядкованого страхом». Вихід? «І не дасть з тою бісівською силою собі ради Захід, ні Україна, коли тій темній силі не протиставить ще могутнішу, ще страшнішу силу ідеалізму, гарячої віри у свою Правду, поставлену над все земське і дочасне, силу мілітантного духа» [12; 5-9].

Такі міркування «правого» сектору світоглядних орієнтацій узгоджуються 3 висновками Карла Маркса - речника «лівої» течії соціально-політичної думки. Його праці, присвячені деспотичній суті московської держави, були в СРСР суворо заборонені. Починаючи з 1302 року і аж до епохи Петра I Москва приростила свою територію більш ніж у 300 разів, «використовуючи при цьому всі засоби: змови 3 ворогом (аби його потім обдурити), пряму агресію, економічну блокаду, шантаж і грабіж, отруєння сусідів-конкурентів, геноцид...». Маркс довів, що «колискою Московії було криваве болото монгольського рабства». Тільки зазирнувши углиб століть, можна збагнути агресивність московських царів, маніакальне прагнення захоплювати чужі землі та впокорювати чужі народи. Московія, як і сучасна Росія, докладала витончені зусилля для розправи з республіками. Почалося з Новгорода $\mathrm{i}$ його колоній, потім настала черга козачої республіки (Маркс мав на увазі Запорізьку січ), завершилося усе Польщею. Між політикою царів і політикою Путіна існує не схожість, а тотожність. Донині Московія грає роль раба, який став паном [13).

Багато що пояснює щодо сучасної політики Росії на міжнародній арені, рівно ж у контексті війни проти України, загарбання Криму програмна стаття Богдана Кистяківського «На захист права. Інтелігенція і правосвідомість» у збірнику «Вехи» в 1909 році. Знаменитий правник розкриває зневажання законності, усвідомлення цілими поколіннями російських людей, у тому числі інтелігенцією непотрібності правосвідомості. Варто застановитися над таким судженням (подаємо в оригіналі): «Притупленность правосознания русской интеллигенции и отсутсвие интереса к правовым идеям являются результатом застарелого зла - отсутствия какого бы то ни было правового порядка в повседневной жизни русского народа. По поводу этого Герцен еще в начале пятидесятых годов прошлого века писал: «Русский, какого бы он звания ни был, обходит или нарушает закон всюду, где это можно сделать безнаказанно; и совершенно так же поступает правительство» [14; 4].

Невипадково світова преса (наприклад, німецька газета «Süddeutsche Zeitung», польський журнал «Nowe Państwo») ще на початку 90-х років XX століття акцентували увагу на тому, що росіянам слід швидше позбуватися імперського комплексу, адже ядерного арсеналу, постійного місця в Раді Безпеки ООН замало для того, щоб претендувати на роль нормальної великої держави; певний рівень добробуту і міцні демократичні структури - неодмінна умова поваги світової громадськості.

Ідейний вакуум сучасної російської політики очевидний. Квінтесенцією російської національної ідеї, російської національної мрії залишається категорія перемоги. Відомий шовініст Олександр Проханов вважає: «Ця категорія календарна, 
історична, метафізична і релігійно-містична... У XXI столітті, як і у попередні, Росії належить здобути надперемогу і знову зробити століття російським... Російська мрія - це мрія про рай, причому про рай для всіх народів землі» $[15 ; 10]$. Політик-провокатор Владимир Жириновский у статтях, виступах у Державній Думі, у науково-публіцистичних брошурах «Иван, запахни душу!», «Русские, жестче взгляд!», що вийшли друком у 2003, 2011 роках у Москві, змальовуючи безрадісну картину російського суспільства, приходить до висновку (цитуємо в оригіналі): «Россия может быть лиш сильным государством с авторитарным режимом, с мощной экономикой и армией» (Жириновский. В. «Иван, запахни душу!». - Москва, 2003, - С. 54).

Виявляти статус ідентичності людини і спільноти медійній сфері, журналістській науці варто на основі інтегративного підходу, що базується на мультидисциплінарності, діалозі різних ментальних культур. Адже техноутопія, так само як і національний егоцентризм 3 неминучим переходом до расизму й ксенофобії, провалились. Часто траплялося, що визволені з неволі народи успадкували по своїх гнобителях дві вкрай шкідливі речі: національну нетерпимість та імперіалістичні тенденції. Відтак щоразу нове національно-політичне обличчя світу та міжнародне співжиття не узгоджувалися з первісними начебто гуманними засадами. Пролілюструємо це таким прикладом - грунтовним макротекстом. Йдеться про фундаментальну статтю «Пісні західних слов'ян. Думки про російську національну свідомість» досвідченого публіциста, працівника Радіо Свобода (російська редакція) Анатолія Стреляного, вміщену, в порядку дискусії, у впливовій московській «Литературной газете» ще 8 серпня 1990 року. (Користаючись 3 нагоди, рекомендуємо засвоїти основні положення наукового осмислення Валерієм Стеценком християнського кордоцентризму «філософії серця» Памфіла Юркевича, опублікованого у Віснику Львівського університету (Серія філософська. - 2010. - Вип. 13. - С. 29-37).

Отже, про суть актуальності й новизни, аргументаційних ресурсів, композиції, виражальних засобів «Пісні західних слов’ян». Маємо своєрідний акцент феномену метаісторії - йдеться, за Сергієм Кримським, про інтерпретацію історичного процессу не як того, що відбулося й відбувається, а як того, що зберігається не тільки у пам'яті людей, а як основоположні цінності.

Тодішня «Литературная газета» ще претендувала на плюралізм думок, не була повністю підпорядкована режимові. Отож на ії сторінках розгорнулася дискусія «Російська ідея: минуле і майбутнє». Мотивація редакції визначалася турботою про «долю Батьківщини, яка знову опинилася на історичному роздоріжжі «Куди йти?». Чи має рацію досвідчений публіцист Анатолій Стреляний, обгрунтовуючи у своїй статті кризу російської національної свідомості? Редакція вважає таку позицію дуже суперечливою і очікує, що дискусія розгорнеться, аби народилася істина». Автор відразу ставить проблему: майже усі російські ідеї, які мали місце в Радянському Союзі на той час, прийшли зі Заходу, точніше із середовища російських емігрантів: «Наші нинішні пісні - це усі пісні наших західних слов'ян, у чому міг би переконатися кожний читач, якби кожний письменник був вихований правилами буржуазної чесності, що вимагає вказувати джерела і користуватися лапками».

А потім на цілій сторінці подає аргументи, посилаючись переважно на знаменитого філософа Георгія Федотова, зіставляючи факти історії із сучасністю, зачіпаючи проблеми ідентифікації народів російсько-радянської імперії, насамперед українців. Росіяни запозичили у Гегеля ідею про особливу роль нації у світі. Емб- 
лематичний письменник Росії Валентин Распутін наголосив, що «Матушка-Росія репрезентує прагнення до святості». Відтак емігрантські письменники визначили мету своєї публіцистики - виховання російської політичної та патріотичної думки. Г. Федотов визнавав, що «лише завдяки Заходові Росія змогла виговорити своє слово», що «культурне життя Росії немислиме без Європи». На думку цього філософа, «найбільша слабкість російського націоналізму полягає у його обмеженому, якомусь тваринному чи рослинному натуралізмі... Для російської людини батьківщина - передовсім не думка і навіть не слово, а звучання, тембр голосу. Якщо додати звичку до пози навколішки, то вже маємо готову формулу «слов'янської душі».

Інші свідчення знаних особистостей, на які посилається Стреляний, стосуються почуття сорому за Росію, яка скалічила себе більшовизмом, вигаданими прізвищами вождів (Лєнін, Троцький та ін.), збурила охлос з його криком, схильністю до різанини. Не маючи, як інші республіки (бодай формально!) свого ЦК, НКВД, Академії наук та ін., Росія і за більшовиків залишалася імперією. Висновок автора: «3 докладним знанням проблеми найавторитетніші з-поміж західних слов'ян говорили про давній гріх культурної Росії перед ії народами. Цей гріх - байдужість до національного питання, до історії та культури народів імперії, особливо слов'янських і передовсім українського. Добром це не закінчиться, - попереджали вони. Сучасній середньостатистичній російській культурній людині Україна також не цікава, вона для неї - Росія, своя. Вона не розуміє, що вона, Україна, може не сказати росіянам за це «спасибі». На моїй пам'яті ніхто з росіян не написав навіть звичайного подорожнього нарису про Україну як Україну». Федотов писав прямо: «Ми завжди любили Україну певною романтичною любов'ю як своє російське, причому найгарніше, найбарвистіше і казкове у російському».

Термінологічні викрутаси сучасних російських вчених, наприклад А. Ципка, про можливість «спільної долі росіян і українців під прапором свободи» остаточно заперечив путінський режим. Однак Анатолій Стреляний ще задовго до його встановлення довів: «Без насильства Росія не зможе нести жодної історичної відповідальності ні за будь-кого, про це можна говорити як про несхитний історичний закон» [16]. Після окупації Криму, розгортання війни на Донбасі у сотнях публікаціях в газетах «День» (Сергій Грабовський, Ігор Яковенко, Наталя Іщенко, Ігор Лосєв, Андрій Плахонін, Лілія Шевцова, Дмитро Шушарін, Роман Гривінський та ін.), «Україна молода» (Григорій Омельченко, Микола Сядристий та ін.). «Факты» (Андрій Іларіонов, Олександр Левченко, Мустафа Джемільов, Курт Волкер та ін.), тижневику «Країна» усебічно й переконливо розкрито злочинну політику царської, більшовицької, нинішньої Росії. Це спричинило до того, що, за свідченням відомого економіста, політолога, колишнього радника російського президента А. Ілларіонова, «за межами Російської Федерації слово «русский» стає синонімом мерзотника» [17]. А Ігор Яковенко з Москви доводить, що «російський телевізор має перетворитися на одне 3 найважливіших джерел доказів злочинів путінського режиму» [18; 27]. Публікації названих авторів, до слова, заслуговують на окреме фундаментальне дослідження як результативні свідчення сучасного етапу ідентифікації російського режиму і нації в цілості.

А щодо України, то давно доведено, що «Москва в Києва говорити вчилась» (Так озаглавлено статтю-дослідження письменника Данила Калиняка у газеті «Україна молода» 5 вересня 2013 року - звертаємо увагу на промовистий підзаголок: 
«Духовним кілерам, перш ніж братися за публіцистику, варто ліквідувати прогалини у власній історичній ерудиції»). Власне, вище зазначене наукове дослідження про «філософію серця» П. Юркевича в контексті поставленої проблеми багато що пояснює і прояснює.

А висновки, скажімо, багатьох польських публіцистів щодо українсько-російських відносин під сучасну пору одним реченням-заголовком схарактеризував відомий журналіст Петро Лісєвіч (Piotr Lisiewicz) - «Більшого чорта для України нема» (Większego czorta dla Ukrainy nie ma // Nowe Państwo. - 2013. - № 12).

Звернемо увагу на те, що поставлена проблема вимагає також глибшого психологічного обгрунтування. Можемо, наприклад, зіслатися на дослідження психології юрби видатним американським суспільним психологом Філіпом Зімбардо. Відомий польський публіцист Анджей Бєлєцький свого часу розмовляв 3 ним на ці теми. Інтерв'ю з'явилося у впливовій польській газеті «Жечпосполіта». Стисло передаємо суть міркувань і висновків фахівця світового рівня. Інтригує вже сам початок:

«Питання: Що вирішує про те, що одні народи йдуть за Гітлером, а інші - за Ганді? Для чого деякі люди вдаються до здійснення жахливих злочинів, а інші - $\epsilon$ готовими з альтруїстичних мотивів ризикувати життям?

Bidnoвidb: Пишучи книжку про Адольфа Ейхмана, Ханна Арендт мала рацію в одному: зло з'являється в дивовижно банальній формі, є справою звичайних людей. Злодієм, вбивцею може виявитися наш пекар, водій автобусу, колега 3 праці. Але Арендт помилилася в іншому, твердячи, що такі люди як Ейхман подібні до листя на вітрі, вписуються в контекст широких історичних явищ, в даному випадку нацистської Німеччини. Інакше кажучи, чи Ейхман був, чи би його не було, Голокост відбувався би так само. Це неправда. Чому? Бо про те, чи здійсниться зло, вирішують одиниці, а не неуникні історичні процеси. У випадку Голокосту - передовсім сам Гітлер. Він виявився каталізатором злочину. Звичайно, мав місце певний контекст: програна Німеччиною Перша світова війна, криза, загальне почуття кривди в німецькому суспільстві. У такій ситуації політики діють банально - шукають прості відповіді на те, чому справи такі погані. У випадку Німеччини могли визнати, що винні у злі багаті євреї і треба на них накласти додаткові податки. Концепція ж Гітлера була іншою. Він вважав, що євреї відповідальні за трагедію Німеччини не тому, що є багатими, а тому, що є євреями. Люди у це повірили. Таким було джерело Голокосту».

Далі з’ясовано причини успіху Гітлера: харизма, контроль над медіями, фанатична віра, пропаганда Геббельса. Цікава така думка: сьогодні, в епоху телебачення, харизма Гітлера вже не спрацювала б. Цитуємо:

«Питання: Чому?

Bidnoвidb: Бо телебачення - це зближення, ілюзія безпосереднього контакту між вождем і звичайною людиною, контакт „один на один”. Особою, яка мала колосальну харизму і це виявлялося через телебачення також, був Іван Павло П. Він також щиро вірив в те, що говорив, але при цьому був винятково людяним. Кожний міг в ньому знайти свого батька, нав'язати безпосередній контакт».

Другий найважливіший механізм керування суспільством - страх. Сталін, на противагу до Гітлера, взагалі не мав харизми. Але був шефом мафії, діяв через створення атмосфери терору, вбивства всіх реальних і потенційних противників, прагнув всіх і все контролювати. Він не був психічно хворим, так само як і Гітлер ним не був. Вони просто хотіли мали абсолютну владу (нині бачимо це на прикладі Путіна). 
Чи прагнення до влади є найсильнішим мотором світового процесу? Наявність влади дає два інших найбільш очікуваних добра: секс і гроші. Люди йдуть до політики власне для того, аби мати владу. Щодо жінок, то вони використовують як владу свою красу.

«Питання: Чи це означає, що в кожному суспільстві маємо близько десяти відсотків людей, які прагнуть добра і десять тих, які здійснюють зло, а решта піде за тим, хто візьме ініціативу на себе?

Bidnoвidb: Я назвав цю пропорцію ефектом Люцифера, улюбленого Ангела Бога, який поступово перетворюється в диявола. Так може статися 3 кожним із нас.

Питання: Існує, однак, оптимістичніший сценарій: ми спроможні піти в напрямку добра. Від чого це залежить?

Biдnовідb: Ми у Сан-Франціско досліджуємо цей процес. Психологія десятиліттями концентрувалася на механізмах зла, аби виявити загрозу для суспільства. Ми й надалі уявляємо собі, що це заслуга людей, які діють самостійно, подібно до середньовічних рицарів. Але це помилка. Героїчні вчинки здійснюються кожного дня звичайними людьми, і власне це спричиняє, що вони стають героями».

Далі Зімбардо розповів про випадок, що його спостерігали у Нью-Йоркському метро, коли одна людина, не роздумуючи, кинулася рятувати іншу людину, яка впала на рейки. 200 осіб мовчки спостерігало це, і лише один, до слова, негр кинувся допомагати потерпілому. Чому власне він? Чорношкірий батько двох дітей фактично ризикував життям, щоб врятувати білу людину. У дослідженнях Зімбардо розрізняють два типи героїв. Перший подібний до героя з нью-йоркського метро, це імпульсивно-реактивний тип: людина ухвалює рішення блискавично, часто ризикує. Другий тип геройства має характер рефлексійний: це людина, яка роками збирає матеріали про корупцію, організовує сітку співпрацівників і врешті знайомить $з$ результатами дослідження суспільство в ім'я загального добра. В обидвох випадках одне є спільним: герой відчуває, що може змінити дійсність. Кожний з нас може в житті здійснити героїчний вчинок, але переважно не зважується на це.

«Питання: Ваша дефініція героїзму має на меті здійснення чину особою в інтересі спільноти, на резигнації з логіки егоцентризму на користь логіки соціоцентричної. Чи це не є засадничо послання Христа?

Bidnoвids: Звичайно, так. Дві тисячі років євангелізації змінюють все таки світ на краще. Цьому сприяє інтенсивний обмін інформацією. Нині важко щось скрити. Змінилися також суспільні норми. Нині не вдаються до суду Лінча. А чи зникне зло назагал? Розмовляв я на цю тему з Далай Ламою, він вважає що зло зникне, коли люди просвітлять свою душу через медитацію. Я керуюся більше суспільною психологією. Треба створювати альтернативну можливість елімінації зла. Я народився на Сицилії. Коли приїжджаю туди і запитую родича - пекаря, чи він допомагає мафії, відповідає - ні! Але за якусь хвильку додає: часами допомагаю грішми. Так трапляється з кожним - коли переходимо межу зла, завжди собі вмовляємо, що це лише на хвильку, що зараз повернемося в інший бік. Але це здійснити виявляється важко. Життя як гірськолижний спуск, який є слизьким. 3’їхати легко, але вернутися назад дуже важко» [19].

Життя вимагає фундаментальних знань. Макротексти саме орієнтують на розуміння дійсності, суті речей. Водночас пропонують кращі рішення. Мусимо забезпечити ефективні контакти з належними пропорціями авторитету і свободи, ієрархії 
та розвитку, зі стабільними організаціями, теж у царині мас-медіа. Тільки на основі ідеалів святої правди-справедливості, рівноправності й взаємозбагачення народів може утворитися цілісна особистість 3 ясним гуманістичним поглядом на світ, імунітетом проти неправди, страху, руйнівних орієнтирів, а також динамічна спільнота на фундаменті несхитних вартостей. 3 цього приводу гостро актуальними залишаються такі судження блискучого тексту Віктора Гюго: «Хіба не існує реально оце таємниче призначення: доповнювати всесвіт іншим всесвітом, до малості одного долучати щедротний надмір другого, збільшувати обшири: тут - свободи, там - науки, там ідеалу, надавати низькому вищої краси, нести в далину нові віяння, сповнювати глибинним теплом планету, гармонійно поєднувати різні світи однієї системи, квапити тих, які відстали, єднати земні творіння?...». Генії за усіх часів саме й підвищували рівень моралі, одухотворювали буття, допомагали іншим збагнути одвічне, сокровенне, «вони не обтяжують цивілізацію пасивом - розчавленими народами» [20; 320].

\section{Висновки}

У нинішній період тотальної стривоженості і страху перед спотвореною тенденцією розвитку сучасних суспільств і формування людської особистості важливо опредметнити у мас-медіа і журналістській науці декілька засадничих речей:

Осмислити хід світового розвитку і викликів, що постали перед сучасною цивілізацією у XXI столітті. Ідеться про макротексти, які подають цілісну характеристику пройдених етапів, виокремлюють раціональне і перспективне окреслення боготвірного феномену людської особистості, а також орієнтиру на «цивілізацію любові» (Іван Павло II);

Дослідження ролі людської особистості з яскраво вираженими вартісними орієнтаціями, плодотворними напрямками розвитку людини, нації, людства в цілості;

Випрацювання несхитних засад світоглядної публіцистики: ідеться про слово, яке визволяє, всупереч слову, яке поневолює. У цьому контексті слід збагатити аргументаційні ресурси текстів на основі найкращих здобутків світової журналістики.

\section{REFERENCES}

1. Jankowicz Grzegorz. «Nowe «Lekcje czytania». - facebook.com/LekcjeCzytania

2. Лісовий В. Історія. Ідеї. Думаючи про цивілізацію // Зустрічі. 1988. Ч. 1-2. С. 21.

3. Франко I. Поза межами можливого // Зібрання творів у 50-ти томах. Т. 45. К., 1986. C. $276-285$.

4. Сціборський М. Націократія. Вінниця, 2007. С. 74.

5. Мислителі німецького романтизму. Івано-Франківськ. 2003. С. 39.

6. Морроу Л. Зло. - «Тайм», Нью-Йорк // За рубежом. 1991. № 31. С. 8-9.

7. Sąd nad XX wiekiem // Tygodnik Powszechny. 2000. № 23.

8. Richard Gott. Maly wielki mit // The Guardian. 2011. 19 oktober (Цит. за: Forum. 2011. 14-20.11).

9. Сюндюков I. Плоди руху століть // День. 2004. 12-13 травня.

10. Астольф де Кюстін. Росія 1839 року // Сучасність. 1993. Ч.1. С. 36, 38.

11. Астольф де Кюстин. Россия в 1839 году. Фрагмент книги // Иностранная литература. 1991. № 7. С. 214.

12. Донцов Д. Передмова / Астольф де Кюстін. Правда про Росію. Торонто-НьюЙорк, 1958. С. 5-9. 
13. Сюндюков I. Що таке Московська держава? Карл Маркс - про методи царських «збирачів земель» // День. 2014. 4-5 квітня, 11-12 квітня.

14. Наше наследие. 1990. № 4. С. 4.

15. Национальная тема. Современные русские писатели думают о православии, самодержавии и народности // Независимая газета. 1999. 2 окт. С. 10.

16. Стреляный А. Песни западных словян. Мысли о русском национальном сознании // Литературная газета. 1990. 8 авг. С. 3.

17. Андрей Илларионов: «За пределами Российской Федерации слово «русский» становится синонимом мерзавца...» // Факты. 2016. 16 дек.

18. Яковенко I. Червона картка для Росії // День. 2019. 15-16 лют. С. 27.

19. Andrzej Belecki. Efekt Lucyfera // Rzeczpospolita. 2014. 20-21 lipca.

20. Гюго В. Мистецтво і народ. Збірник. Київ, 1985. С. 320.

21. Чаадаєв П.Я. Філософічні листи. Апологія божевільного. Уривки та різні думки (1828-1850-ті роки) / Упор. М. Г. Житарюк. Вид. перше. Львів, 2005. 176 с.

\title{
THE MAIN EMPHASIS OF THE MODERN AGE: MEDIAIZATION OF THE CONCEPT OF THE IDENTITY OF THE PERSON AND THE COMMUNITY
}

\author{
Josyp Los \\ Ivan Franko National University of Lviv, \\ Generala Chuprynky Str., 49, 79044, Lviv, Ukraine \\ e-mail:jlos@gmail.com \\ https://orcid.org/0000-0002-7531-8043
}

In the article, on the basis of modern researches on the identification of the human personality and the national and social community (scientific resources and mass media), the issues of definition of the essence and role of the individual and communities in the modern conditions of «changing the epochs» from total anxiety to the organic ordering of being are considered. In the current period of total anxiety and fear of a distorted trend in the development of modern societies and the formation of a human person, it is important to outline several basic things in mass media and journalistic science:

1) Understanding the course of world development and the challenges faced by modern civilization in the 21 st century. It is a question of macrotexts that provide a coherent description of the stages that have passed, outlining the rational and perspective vision of the divine phenomenon of the human person, as well as the reference to the "civilization of love" (according to John Paul II);

2) Investigation of the role of the human personality with pronounced value orientations, fruitful directions of development of man, nation, humanity as a whole;

3) Elaboration of the precise principles of worldview publicism: it refers to a word that frees up, contrary to the word that enslaves. In this context, it is necessary to enrich the argumentative resources of texts based on the best achievements of world journalism.

Key words: personality, community, ideals, identity, modernity, mass media, argumentation, wholeness, historical consciousness. 